\title{
Language Choice As The Way How The Local Diaspora In Bali Maintain Their Social Identity
}

\author{
Ida Bagus Putra Yadnya ${ }^{1}$, Made Dhanawaty ${ }^{2}$, Made Wiasti ${ }^{3}$, Nyoman Seri Malini ${ }^{4}$ \\ \{putra_yadnya@unud.ac.id¹,md_dhanawaty@unud.ac.id², made_wiasti@unud.ac.id³, \\ seri_malini@fs.unud.ac.id ${ }^{4}$ \} \\ ${ }^{1234}$ Udayana University Bali, Indonesia
}

\begin{abstract}
Maintaining the use of mother tongue in interacting, switching to using the word of the host, or using ethnic languages side by side with the host language in a new place are basic issues that are faced by migrants as a diaspora community. This research is intended to provide evidence of the phenomena of communication and social identity in order to find the right accommodation model that must be carried out by the diaspora and ethnic Balinese communities in interacting that can overcome various disharmonies. It is sociocultural using a qualitative approach conducted at two locations of Muslim diaspora communities in Bali. The data were collected through questionnaires, in-depth interviews, and direct observation. The analysis was carried out qualitatively by applying language choice and linguistic accommodation theories. The result of the analysis is presented through interpretive descriptive explanations. The research findings show that language choice turned out to be evidence of how that most diaspora communities see mother tongue as an essential means of maintaining their social identity and always try to use mother tongue in various domains of activity. The vitality of mother language is reflected from the language choice and attitude of the diaspora communities in the daily life. As social beings, as speakers in a prominent communicative interaction, they generally try to adapt themselves to their interlocutors both verbally and nonverbally, in other words carrying out linguistic accommodation and social accommodation
\end{abstract}

Keywords - language maintenance, mother tongue, diaspora community, language choice, social identity

\section{Introduction}

As a phenomenon of cultural mobility the diaspora communities can no longer be considered only as a group of people with their demographic characteristics, but as humans who have a culture, including the value system, social system, and material culture including language. Migrants as diaspora communities are always to decide whether maintaining the use of mother tongue in interacting, switching to using the language of the host, or using ethnic languages side by side with the local language in a new place to establish positive contacts with 
the host society, and at the same time maintain their ethnolinguistic heritage. Studies on the relationship between identity and minority language maintenance and shift have been done by many authors [1], [2], [3], [4], [5], [6], [7].

The plurality of languages or the presence of various languages in the Province of Bali is due to the events of language contact by different ethnic groups who inhabit Bali, both ethnic migrants through migration and Balinese as natives. Sociolinguistic researches on Balinese diaspora (transmigrants) living in various regions in Indonesia, especially concerning its linguistic aspects, on one side, have been carried out. [8], [9], [10], [11], [12] examined several social aspects of the language of Balinese transmigrants in Lampung, including the construction of ethnic identity, patterns of language use, linguistic characteristics, and the continued use of Balinese. However, the research on the diaspora community living in Bali, on the other side, is limited and is more studied from an anthropological and historical perspective. Hence, how the diaspora community see mother tongue as an essential means of maintaining their social identity and always try to use mother tongue in various domains of activity is significant enough. The success of language maintenance in minority groups is highly dependent on the perception of the vitality that minority group members attach to their language. This research is intended to provide evidence of the phenomena how diaspora communities see mother tongue as an essential means of maintaining their social identity and always try to use mother tongue in various domains of activity.

\section{Methods}

This research is intended to provide evidence of the phenomena of communication related to social identity which focuses on the maintenance of mother language in diaspora communities in Bali. It is a sociolinguistic study on the Muslim community using descriptive qualitative methods in two regencies namely (1) Loloan Muslim diaspora community, in Jembrana Regency; and (2) Pegayaman Muslim diaspora community in the Regency of Buleleng that had lived in Bali for more than a generation. The data were collected through questionnaires, in-depth interviews, and direct observation. The selection of the two diaspora communities is based on subject homogeneity in terms of place and time. In terms of location, geographically they come from the area or island closest to Bali, namely Java to the west. From a time perspective, the two diaspora communities are the result of migration that has long been in existence, and they have settled in Bali for more than a generation.

Sociolinguistic questionnaire was distributed to 30 people from each location to get data related to language attitude and language choice. The questionnaire was in principle designed based on [13], [14], [15], [16], [17] which of course had been adjusted for this study. The questionnaire consists of three sections including demographic data about their background, the language used in different domains including home, school, neighborhood, workplace, religion, and their attitudes towards mother tongue. In the process of collecting data, participatory observation, interview, survey methods, were used. The analysis of language choice and attitude was done quantitatively using simple non parametric statistic to support qualitative description. Sociolinguistically, the analysis was carried out qualitatively by applying language choice and linguistic accommodation theories. 


\section{Result and Discussion}

Diaspora communities have a tendency to adapt their communication patterns in interacting between ethnic groups to their environment. The vitality of mother language is reflected from the language choice and attitude of the diaspora communities in the daily life. In the Loloan diaspora community, Malay becomes the main choice. Most people claimed that the use of Malay language is still strong, especially when talking to families and people from one ethnic group. This happens both in the realm of family, work, and religion. Most respondents (range $63.3 \%-93.5 \%$ of respondents) use Malay when talking to family, for example, father, mother, grandfather, grandmother, and sister/brother. Malay has become the preferred language again when there are family gatherings. As many as $82.1 \%$ of respondents claimed to use Malay when there was a family meeting. In the realm of religion, especially when there are religious gatherings outside the mosque, $82.8 \%$ of respondents claim to use Malay. This shows that in the daily life of the Loloan community, Malay becomes the main choice. This is again seen in the use of language when worshiping at the Mosque. As many as $51.6 \%$ of respondents use Malay to carry out their worship. The dominant use of Malay in the Loloan diaspora community is seen significantly in certain personal emotional expressions. Most respondents $(83 \%$ to $90 \%)$ choose to use Malay to express feelings of happiness, anger, and when expressing ideals.

Among Pegayaman Muslim community in Buleleng, demographic data shows that out of 30 respondents, 29 stated that their mother and father's language was Balinese (96.7\%). From the data as a whole, the majority of respondents use Balinese in various domains and situations, particularly in the realm of family and when the interlocutors come from the same ethnic group. In the realm of family, all respondents $(100 \%)$ use Balinese when talking to fathers, mothers, grandfathers, grandmothers, and sisters/brothers. This shows that the Pegayaman diaspora community has considered Balinese as part of their identity. Balinese is again the main choice when there are family gatherings, as many as $92.9 \%$ of respondents claimed to use Balinese. In the neighboring domain, Balinese is always the main choice when the interlocutor is from the same tribe. In the realm of religion, the language used when worshiping is Arabic. This shows that the majority of Pegayaman residents are Muslim. The use of Balinese is again seen in the situation after worship. The use of Balinese again increased when there were religious gatherings outside the mosque. In expressing personal feelings, most respondents prefer to express it through Balinese. When happy, $83.3 \%$ of respondents expressed it in Balinese. Meanwhile, $93.3 \%$ of respondentsuse

Balinese to express emotions of anger / stress. Finally, when expressing dreams, $82.8 \%$ of respondents prefer to use Balinese. As social beings, as speakers in a prominent communicative interaction, they generally try to adapt themselves to their interlocutors both verbally and nonverbally, in other words carrying out linguistic accommodation and social accommodation. Verbal adjustment is done by the speaker by modifying his/her speech so that it becomes similar to the interlocutors. From this description, it can be seen that the Pegayaman diaspora community has assumed the Balinese language as part of their own community and considers themselves more Balinese than the diaspora. This fact can be explained by the statement of [18] that language shift is one of the results of a long process of language choice by the speech community. Language shifting simply means that a language community no longer uses a particular language but moves to another language. When language shifts occur, people in general collectively move away from the language used by their parents as happened to the Pegayaman people who historically came from outside Bali (Java and Sulawesi).

Someone who chooses language in his communication is actually implementing his communicative competence, or is showing his communicative performance. As a behavior, 
language selection is essentially an act or behavior in using the chosen language based on the available situation. In the neighboring environment, the choice of Malay is especially evident among Loloan community when talking to neighbors from the same tribe. As many as $93.5 \%$ of respondents claimed to use Malay when speaking with neighbors who were of the same ethnic group. This also happens when shopping for goods at a shop with owners from one tribe. In terms of talking to neighbors or shopping in stores that are not from the same tribe they use more Indonesian (above $40 \%$ of respondents). In the realm of work, Malay language remains the choice, especially when speaking with interlocutors from the same ethnic group (100\%). When talking with the boss of the same tribe, $87 \%$ of respondents claimed to use Malay. Likewise when talking with friends of the same tribe, $96 \%$ of respondents chose Malay. This situation also occurs when talking to clients of the same tribe $(95.7 \%)$ is different from when talking to different-ethnic clients who tend to use more Indonesian (65.2\%). This trend occurs both when discussing work topics or general topics.

A person's decision to choose a language or use one of the language codes depends on the cost or benefit which is perceived to be obtained. In the school realm, Pegayaman community, in Buleleng, as many as $65.5 \%$ of respondents claimed to use Indonesian when talking to teachers. Meanwhile, 55.6\% of respondents claimed to use Balinese when talking with friends. The number is not so far from respondents who choose to use Indonesian, which is $40.7 \%$. In the realm of work, respondents prefer to use Indonesian when the interlocutors come from different ethnic groups. When talking with coworkers, $66.7 \%$ claimed to use Balinese. When dealing with the boss of the same tribe, the use of Balinese and Indonesian is quite balanced. As many as $45.8 \%$ of respondents claimed to use Balinese when speaking with ethnicity superiors. Meanwhile, $54.2 \%$ of respondents chose to use Indonesian. This also happens in situations when giving instructions or directions verbally to co-workers of one tribe. Half of the respondents chose to use Balinese and the other half used Indonesian.

The attitude of language becomes one of the important things and cannot be ignored because it is related to the existence of a language. The attitude of language reflects the survival of a language. From the attitude of language, it can be assessed how an individual's view of a language and from there can influence its use even views of a particular social group. Language attitude is a person's perception or view of a language, whether happy or not towards the language, so that the attitude of language influences the choice of language. Lambert states that the attitude consists of three components, namely the cognitive component, the affective component, and the conative component. Language attitudes can emerge in the form of language loyalty which encourages the speakers of a language to maintain their language and if necessary prevent any influence from other languages. In addition to loyalty to language, a sense of pride in language can also encourage speakers of a language to develop its language and use it as a symbol of identity and community unity. In addition to loyalty and pride in language, awareness of the existence of language norms encourages speakers to use their language carefully and politely which is one of the factors that has a profound effect on the use of language.

Attitudes toward mother tongue, in general the Loloan people show a positive attitude towards their mother tongue. Recognition of the respondents revealed that their native language (in this case Malay) is the most beautiful language and is a symbol of ethnic identity of the individuals. As many as $74.2 \%$ of respondents stated strongly agree that their mother tongue is the most beautiful language. Furthermore, there are $50 \%$ of respondents who strongly agree and $46.7 \%$ of respondents agree that their mother tongue is a symbol of their ethnic identity. The symptom of keeping Malay as a mother tongue in Loloan society is also apparent. As many as $58.1 \%$ of respondents agreed that children need to be able to communicate effectively using 
mother tongue. As many as $53.3 \%$ of respondents also strongly agreed that their mother tongue is related to ancestral heritage and history. From the two statements, we can see the defensive symptoms of Malay because people consider Malay language as a historical legacy whose existence needs to be preserved for generations to come. In the statement that their mother tongue is important to be used in every aspect of daily life, there are $40 \%$ of respondents who are doubtful about the statement. This is quite reasonable because in everyday life, Indonesian has become the choice in various fields, such as school and work.

In the section on language attitudes towards Balinese, most Loloan respondents felt doubtful about the statement given. It was revealed that as many as $50 \%$ of respondents said they did not agree and that the Balinese language had become their identity. This was also supported by $39.3 \%$ of respondents who felt doubtful about the statement. Furthermore, there were $64.3 \%$ of respondents who disagreed that Balinese allowed them to express their emotions freely. In fact, $64.3 \%$ of respondents stated that they did not agree that Balinese was the unifying community in Bali. Regarding the statement that Balinese is a language that is very proud of, there are $50 \%$ of respondents who are doubtful. From these results, it can be said that the Loloan people have a positive attitude towards Malay language which has been regarded as their identity. Not only that, Loloan people have a tendency to maintain Malay language to the next generation.

Demographic data shows that out of the 30 Pegayaman Muslim community respondents, 29 stated that their mother and father's language was Balinese (96.7\%). As seen in the description of language choices, from the data as a whole, the majority of respondents use Balinese in various domains and situations, especially when used in the realm of family and when the interlocutors come from the same ethnic group. In line with the choice of language, the attitude of the Pegayaman community towards their mother tongue also tends to be positive. There were $48 \%$ of respondents who agreed and added $44 \%$ of respondents stated that their mother tongue was the most beautiful language. Even more significant is that there were $66.7 \%$ of respondents who agreed that his mother tongue was a symbol of his ethnic identity. Furthermore, there are $43.3 \%$ of respondents agree that their mother tongue is important to be used in daily life. These results indicate that the Pegayaman community has a positive attitude towards their mother tongue. This positive attitude also is apparent in the religious realm. There are $70 \%$ of respondents who agree that mother tongue is important to be used in religious activities and religious gatherings. These results indicate that their mother tongue has entered even a fairly personal domain.

\section{Conclusion}

Language maintenance is a form of real effort to preserve and maintain a cultural identity that is inherent in society. The success of language maintenance in minority groups like diaspora community is highly dependent on the perception of the vitality that minority group members attach to their language. From language choice and attitude perspective of the diaspora community the result shows that most diaspora communities in both Loloan and Pegayaman see mother tongue as an essential means of maintaining their social identity and always try to use mother tongue in various domains of activity. Language can only live if it is constantly passed on. 


\section{References}

[1] H. Giles, "Ethnicity markers in speech," in Social marker in speech, K. R. Scherer and H. Giles, Eds. Cambridge: Cambridge University Press, 1979.

[2] H. Giles and P. Johnson, "Ethnolinguistic theory: a social psychological approach to language maintenance," Int. J. Soc. Lang., vol. 68, 1987.

[3] H. Giles, R. Bourhis, and D. M. Taylor, "Towards a theory of language in ethnic group relations," in Language, ethnicity and intergroup relations. European Monographs in Social Psychology, H. Giles, Ed. London: Academic Press, 1977.

[4] J. Edwards, Linguistic minorities: policies and pluralism. London: Academic Press, 1984.

[5] J. Edwards and J. Chisholm, "Language, Multiculturalism, and identity: A Canadian study," J. Multiling. Multicult. Dev., vol. 8, no. 5, 1987.

[6] L. B. Breitborde, Speaking and Social identity: English in the lives of Urban Africans. Berlin: Mouton de Gruyter, 1998.

[7] D. Carbaugh, Situating Selves: The communication of social identities in American scenes (Human communication processes). New York: State University of New York, 1996.

[8] I. G. M. Sutjaja, "Language Change: The Case of Balinese in the Transmigration Areas of Lampung, Sulawesi, Sumbawa, and Timor," Res. Rep. funded by Toyota Found., 1992.

[9] I. Kismosuwartono, Parenting system of Javanese and Balinese Transmigrant Farmers' Families in the Transmigration Area of Ruktiharjo Village, Seputih Raman District, Central Lampung Regency, Lampung Province (Comparative Study of Javanese and Balinese Farmers' Families). Denpasar: Fakultas Sastra Universitas Udayana, 1991.

[10] N. M. Dhanawaty, Dialectal Variations in Balinese Language in Transmigration Areas in Central Lampung (Dissertation). Yogyakarta: Universitas Gajah Mada, 2002.

[11] I. B. P. Yadnya, S. N. Malini, and N. Dhanawati, "Linguistic and Social Accommodation of intra Ethnic in Lampung Province: Towards the Pattern of Overcoming Social Disharmonization," Res. Rep. DIKTI's Natl. Strateg. Compet. Grants, 2010.

[12] N. L. N. S. Malini, Dynamics of Balinese Language in Transmigrant Areas in Lampung Province. (Dissertation). Denpasar: Universitas Udayana, 2011.

[13] J. Fishman, "Language maintenance and language shift as fields of inquiry," Linguistics, 1964.

[14] J. Fishman, Language Loyalty in the United States. The Hague: Mouton and Co, 1966.

[15] B. Dweik, "Linguistic and cultural maintenance among the Chechens of Jordan," Lang. Cult. Curric., vol. 13, no. 2, 2000.

[16] B. Freed and J. Collentine, "Learning context and its effects on second language acquisition," Stud. Second Lang. Acquis., 2004.

[17] M. Al-khatib and M. Al-Ali, "Language and cultural maintenance among the Gypsies of Jordan," J. Multiling. Multicult. Dev., vol. 26, no. 3, 2005.

[18] R. Fasold, The Sociolinguistics of Society. Oxford: Basil Blackwell, 1984. 